\title{
Commuters' Fear of Crime and the Road Transport Industry: A Study of Ibadan-Sokoto Transport Corridor
}

\author{
R.A. Okunola Department \\ of Sociology University of \\ Ibadan, Nigeria
}

DOI: 10.36108/NJSA/9002/70(0120)

Vol. 7 Issue 1, 2009

\begin{abstract}
Human activities are conducted over space and this includes movement from one geolocation to another. This major need for movement is mostly serviced by the road transport industry made up of public and private investors. To protect consumers in this sector, various policies and regulations have been put in place not only to ensure value for money and standard but also for the safety and security of commuters and transport operators alike. This however seems like a mirage as criminal activities are steadily shifting from neighbourhoods and settlements to the highways. This paper is an effort towards understanding the situation of things in terms of validity of various reports and extent of such crimes along the Ibadan-Sokoto transport corridor, the state of fear amongst commuters, the effects of this on the road transport industry and stakeholders (transport owners, community and the commuters). The findings showed the apprehension of commuters along this highway and increasing criminal activities in specific points on the highways. Aside from measures taken by commuters and commercial drivers to 'beat' such criminals, communities along the corridor have established local guards to protect commuters who often pay tokens to maintain their services. It is concluded that there is need to re-address the country's highway policing strategy and thus look for ways to integrate and provide technical assistance to local vigilantes who are becoming increasingly relevant on long distance routes in Nigeria.
\end{abstract}

\section{Key Words: Fear of crime, Commuters, Transport corridor, Crime statistics, Policing}

Though the fear of crime is closely related to the level of crime and tends to increase as crime rises, it cannot be seen as a mere function of levels of criminal activity at any given time (Lucial Zedner, 1997:586)

\section{Introduction}

Empirically, crime is a common feature of social life in all types of society. However, the scales and rates of the incidence and prevalence vary across societies and periods. Given the varied nature of crime, societies have devoted vast amount of human and material resources to its prevention and control. This is because crime threatens peace, development and security in society. Thus, the primary task of the police (ancient and modern) and other armed forces is to acquire necessary instrument and skills to manage crime in society.

Over the years, there have been growing concern and fear by the government over reports of widespread incidence and escalation of crime in Nigeria (Alemika, 1997). Apart from media reports which have fuelled basic fear and mass hysteria, scholars have equally devoted considerable attention to 
its analysis However, the last few years have spurred our knowledge of crime in Nigeria hitherto limited to crime around neighbourhoods and business centres to much emphasis on highway crime that is fast becoming the order of the day in modern Nigeria. The growing media reports show that both the poor and the rich suffer the same fate on highways alongside the bolder and sophisticated nature of bandits operations (Agbola, 1997), while the solution does not appear to be in sight. This paper is an attempt to contribute towards the analysis of crime on Nigerian highways.

\section{Objectives}

The broad objective of this study is gain knowledge on commuters' perspective of fear of crime along Ibadan-Sokoto transport corridor. The specific objectives include:

1. To examine the nature and trend of highway banditry on Nigerian roads.

2. To investigate the fear of crime amongst commuters

3. To look into the effects of highway crimes on road transport industry.

4. To analyse the responses of both commuters and road transport workers to highway crime.

5. To offer suggestions for crime control and prevention of highway crime in Nigeria.

\section{Road Transportation and Armed Banditry in Nigeria}

To contextualize the review, we first examine road transportation in Nigeria in an historical perspective. Transportation is a requirement for every nation and movement of goods and people from one place to another and is critical to the maintenance of strong economic and political ties between regions in the same state (Husher, 2005). Pre-colonial transport and trade systems in Nigeria were limited to porterage over land by animals and humans, as well as on small boats over the many waterways through southern and central Nigeria. Such states had extensive trade routes within their own territory that also included moving goods across the desert trade routes of North Africa and later to the coast to trade with Europeans. During these periods, roads were maintained by local leaders using hired labour, or conscripted locals on the basis of age (Husher, 2005).

With colonialism, the British colonial masters developed modern transport infrastructure that clearly revealed their intention, which is basically to make ruling over the area as well as resource extraction easier. Thus, resulting from colonization, Nigerians took advantage of the introduction of automobiles by developing taxi and goods transport services. The country had witnessed some growth along this modern line. To date, Nigeria's existing transportation is essentially unimodal as over $90 \%$ of domestic freight and passengers are moved by road transportation with the balance shared among railways, air transport and inland waterways (Filani, 2003). The major land transport 
infrastructure in Nigeria consists of $32,000 \mathrm{~km}$ of Federal highway; 30,500km of State roads and $130,000 \mathrm{~km}$ of local roads (Buhari, 2000). Even though Nigeria has the largest road network in West Africa and the second largest in south of the Sahara, the Nigerian roads are poorly maintained and are often cited as a major cause for the country's high rate of traffic fatalities (Adebayo 2009; Wikipedia, 2009; Wahab, 2008), thus posing a great burden on Nigerians and Nigerian road users. The hazard on the passengers is not limited to this; the more worrisome aspect of it is the burden of crime on the highways especially highway robbery that has grown over the years as part of the security crisis in Nigeria. Basically, crime is a common feature of social life in all types of society.

While the scales and rates of incidence and prevalence vary across societies, a vast amount of human and material resources have been deployed for its prevention and control. Further, the problem of highway banditry and or robbery is not new in society. Akinwumi (2001) showed clearly that armed banditry was widespread on trade routes in pre-colonial Africa and often with the active support of some top political elite as can be cited in the activities of bandits and pirates in the $19^{\text {th }}$ century Yorubaland (Falola, 1995:96). Most of the trade routes brought enormous wealth, but they were infested with pirates and armed bandits. The incessant activities of these bandits or incorrigible robbers', had negative consequences not only on the revenues from trade but also on the image of the states. According to Akinwumi (2001), in the case of pre-colonial Borgu, such robbers usually operated in gangs under the leadership of a powerful prince, who provided the weapons and also directed operation. In some cases, the gang could be up to 100 to 400 robbers. Using various tactics that are context specific, such gangs use horses, spears, bows and poisoned arrows. The victims as well as individual pre-colonial state responded to these challenges in several ways, including moving in large groups, getting armed, to the creation of anti-robbery squad teams by state governments, to ensure safety of the routes for the flow of goods and sustenance of the wealth being generated on the routes. However, such efforts were fragmentary, loosely coordinated and did not totally eradicate the phenomenon (Akinwumi, 2001).

The emergence of the modern state was to change all these arrangements with the creation of modern police and policing systems. The modern police that emerged became more embracing and had a special unit for ensuring security and safety on the highways. The question is: to what extent are road users assured of safety and security under this modern arrangement in Nigeria? The fact that crime statistics in Nigeria do not clearly show the rates of arrests for crime on the highways makes it difficult to be able to give a definite answer for the above question. In same vein, the extent of crime on the highways will be difficult to ascertain. We can move closer to the understanding of these dark alley figures by examining the fear of crime amongst those using the highways. 


\section{Fear of Crime}

The threat crime poses to peace, development and security has continued to create fear in the minds of the people. Numerous studies have been conducted on fear of crime (Agbola, 1997; Albert, 2003; Fabiyi, 2004; Reid, 2008). In the words of Maxfield (1984:3), the concept of fear of crime refers to perceived threat to personal safety rather than threats to property or mere generalized perception of risk. From this definition, the construction of the fear of crime may then be as closely related to feelings of powerlessness or vulnerability as it is to calculated perception of risk (Zedner, 1997). Fear of crime varies according to where people live and is affected by where people live within housing projects (Fabiyi, 2004; Reid, 2008). The degree of fear is equally influenced by the nature of social interaction correlates.

According to Fisher and Nadan (1995), fear is greater at night than during the day. Research suggests that women and elderly have the greatest fear of violent crime but they are less likely than young people or than men in general to become victims. Furthermore, both women and elderly may perceive themselves as more vulnerable to crime and less able to protect themselves from violent predators than men and the young do. In addition, it was further shown that compared with men, women take more precautions to protect themselves and are more likely to avoid being abused on the street at night (Reid, 2008). The literature has equally demonstrated that fear is greater especially when (a) there are places for potential offenders to hide and wait for their prospective victims, and (b) there is lack of prospect (the ability) to obtain an open view of the area by looking into or walking through the areas.

Also relationships have been found between race, culture, fear of crime and effects of local/national television news in creating fear. It was further stressed that the fear of crime may contribute to widespread ownership of guns (Reid, 2008). In similar vein, Fisher and Nadan (1995) suggested that fear of crime should be analyzed more carefully in terms of the environment and those factors that might create unrealistic fear. In the analysis of fear of crime, scholars (Williams and Dickinson, 1993; Sundeen and Mathieu, 1976) have identified fear spots. These are specific places or areas where individuals feel fear of being victimized, but where crime may not be frequent or where the police may not have recorded any criminal incidents either during the day or at night.

Some of these fears are realistic and others are not (Reid, 2008); and crime surveys have produced problematic data that appear to show that levels of fear are far from closely correlated with actual risk (Zedner, 1997). In this context, others (for example, Zedner, 1997) have argued that the relationship between risk and fear often stem from methodological issues, two of which are relevant here. These include how to control for variants in respondents' willingness to admit such fears and how to frame questions so as to identify the nature and level of this fear without distorting the data by importing other anxieties. 
The above notwithstanding, it is obvious that the fear of crime is widespread and has changed peoples' social life in society in many ways. This therefore necessitates the need for its analysis with a view to having a proper understanding of its causes and to alleviate it.

\section{Crime on Nigeria Highways}

As noted earlier, armed banditry on the highways is an old phenomenon and it had posed a challenge to commuters over the centuries. Documentation of these incidents is however scanty and limited to some reports at different Police posts/offices along the highways. However, newspaper reports of victims' narrations abound. Two examples are given below:

In a well publicized incident last year, an east-bound luxurious bus was diverted into the bush somewhere between Abuja and Lokoja, late in the night, where the passengers were subjected to unspeakable torture. Their valuables were stolen, the females, raped, and, to complete the round of brutality, they were all stripped naked and ordered to run into the darkness while the vehicle was driven away with their clothing (The Statesman, 2006).

Another occurrence, not long ago, along the Asaba-Benin expressway confirmed the desperation and viciousness of the men of the underworld. That night, the passengers were forced out of their bus and commanded to lay face-down on the road, while their property was being plundered. A truck later crushed the victims, including a pregnant woman, while still lying face-down (Thisday, 2006).

As noted above, it is difficult to get any statistic on the extent of highway crime in Nigeria but the high rates of crime and violence keep the highways bloody and boiling (Obono, 2007). These attacks usually occurred at some dark spots like Ife-Ibadan roads, Owo road in Ondo State, Okpella in Edo State and Okene in Kogi State (Enekwechi, 2008). The regular and similar patterns of such robbery occurrences had remained a cause for concern to many motorists, especially as one could easily see police patrol vans and personnel very close to the scenes of such robberies. Despite public-private partnership which propels key programmes and policies of government, insecurity and real threats to lives and property loom large on highways and cities. From Lagos to Kano, Enugu to Abuja, Ibadan to Sokoto to mention but a few, these trajectories of problems are replicated in increasing magnitude. Yet, the need to make the highways serene and comfortable for drivers and passengers cannot be overstretched. This is the tall task confronting government, and security agencies in Nigeria.

Media reports show the trend in the mode of operations of highway bandits in Nigeria, which involves operating in large numbers, sometimes posing as 
passengers, boarding same vehicles and operate on board after departure in the middle of a journey (Thisday News, 2003). In this way, they overwhelm and intimidate guards, frighten innocent citizens and sometimes send the police and other security personnel scampering for safety in situations where the bandits are more equipped. The incidence of gang robbery on the highways is also on the increase as many notables and commoners have had their share and many Nigerians including those in the diaspora are now weary about travelling to Nigeria during festival periods and other times because of safety reasons. Nigeria has been turned into a place of fear by bands of armed robbers and kidnappers. Consequent on the above, most embassies in Nigeria are placing warning alerts on their respective websites for those planning to travel on Nigerian roads. An example of such goes thus:

There has recently been an increase in the number of robberies and kidnappings in Abia, Edo and Anambra States; in the latter particularly along the Enugu-Awka-Onitsha expressway. Travellers should exercise caution when driving outside cities, consider travelling in convoy, and avoid making any journeys that would involve travel after dark (European Union Travel warnings, August 2009).

Ginifer and Ismail (2003) observed the rise in Small Arm and Light Weapon (SALW) and its consequences, alongside all forms of criminality, especially armed robberies in residential neighbourhoods and along motorways both during the day and night in Nigeria. The failure of the police service, in spite of a series of highly publicized police actions ('Operation-Fire-For Fire', for instance) and force expansion has led to increase in criminality. This subsequently gave rise to self-help security measures by the citizenry through vigilante groups. However, the two sides seem to be overwhelmed by the escalating rise in armed criminality. Over the past five years, armed criminality has been transformed into organized banditry, piracy, bunkering and hostagetaking in the oil rich Niger-Delta region. Uzokwe (2003) noted that most armed robbery incidents on Nigerian highways are carried out near potholes. Knowing that motorists would slow down for potholes, they seize this opportunity to stage their nefarious activities/trade. Potholes have also been identified as culprits in several deadly accidents that have occurred on Nigerian roads. Unsuspecting motorists chance onto them and because they have very little time to react, they swerve and sometimes get into fatal accidents. Statistics attributing many highway accidents to the presence of potholes are sufficient conviction for the government on the need for reasonable budgetary allocation for the highway construction.

Petty crime is common in the entire country including the highways and this includes common crimes such as armed robbery, murder and carjacking. Armed robberies are usually committed at knife or machete point. The use of 
home-made weapons in all crimes has increased to an alarming level. In 2005, armed hold-ups and car hijackings became increasingly common across Nigeria. The year 2006, in particular, saw an increase in the sophistication of criminals in conducting surveillance on their victims especially in carjacking and organized crime. Highway bandits continue to get away with simple road barricades used to waylay their victims. Residential break-ins are generally low and do not pose a threat as such. However, many people live behind barricades of window grilles, alarm systems, night guards and security lights (Dawha, 1996; Agbola, 1997; Albert, 2003; Fabiyi, 2004).

Part of the crime problem is blamed on the country's porous borders. The Benin-Nigerian (Seme) border is particularly notorious for all sorts of illegal activities. Gangsters are known to operate on both sides of the border, launching attacks on one side and seeking shelter on the other. The networks on each side sustain the illegal activities. Highway banditry has forced drivers to travel in armed convoys on main roads in the north. Still, the public continues to fall prey to highway bandits. In May 2006, bandits between Niger and Benin Republics stripped a bus-load of passengers of all valuables and slit the throat of a woman who had tried to resist. This continued lawlessness forced the Minister of State for Defence to call in the army to help (Chikwanha, 2007).

Many reasons have been adduced to explain the upsurge in crime. One hackneyed thesis that has been bandied about is the infiltration of foreign bandits through the country's porous borders. While several foreigners from neighbouring countries have been captured or killed over the years in response to this thesis, the rise in crime rate has not been abated. Evidently, Nigerians commit more than a few of the robberies and in many cases, allegedly with the direct or indirect connivance with security agents (Umaru, 2004; Ikhurionan, 2003).

For obvious reasons, many concerned Nigerians for the most part, point accusing fingers at the police. But other security agencies are equally culpable. Obasanjo did observe, for instance, that "the custom man is the chief smuggler". Similar vile but valid comments can be made with respects to many other security agencies. Under such depressing circumstances, as the former President queried, in anguish, "What do we do?" (Shettima, 2006). As he rightly said, the police are hiring out their guns to armed robbers, what will stop the same police from 'selling' the right of way in the use of the roads to armed robbers? It becomes clear that ordinary Nigerians are powerless and bewildered by the sheer brazenness of bandits on the highways.

\section{Fear and Reportage of Crime on Highways}

The fear of crime in today's society can lead to change and adaption of new lifestyle in many ways (Larkin, 2008). It can restrict our working and social lives to such a degree, which may if not checked, become quite threatening. 
Being involved in an incident or some form of attack whilst driving may influence some people into not using their vehicles as often as they may wish.

Newspaper and television reports have often increased the fear of violence by the reporting of any incident or attack involving motorists. This is not a criticism of the media, but it should show that because such incidents merit the attention of the press, the incident itself is newsworthy and not simply an everyday occurrence. If such incidents went unreported, it would at least indicate that they were 'commonplace' and subsequently not worth reporting. The rarity of any event is often in relation to the amount of publicity given.

In view of this, in future, if one hears of any such incident, which may occur, one should not automatically assume that it is happening everywhere and that it will happen to anyone. It is pertinent to learn from the incident in order to ensure that one will not become a victim of a similar incident. The time to be concerned is when such happenings are not reported as widely as they occur. This would usually indicate that they are 'commonplace' and an everyday occurrence.

\section{Theoretical Framework}

Crime, according to Brantinghaam and Brantinghaam (1981), is complex and it occurs when four things are incongruent - a law, an offender, a target and a place. The place demonstrates the spatial context of crime. In the same vein, the fear of crime cannot but be analyzed more carefully in terms of the environment and the cues that might create fear (Fisher and Nadan, 1995). Against this backdrop, this study adopted the Routine Activities Theory as originally developed by Cohen and Felson (1979) and subsequently elaborated mostly by Felson, (1994) and Eck (1995). The theory simply holds that the probability that a violation will occur at any specific time and place might be taken as a function of the convergence of the likely offenders and suitable target in the absence of capable guardians.

The Routine Activities Theory was proposed by Lawrence Cohen and Marcus Felson in 1979 (Miller et al., 2006:81) as a response to the crime rate of the United States during 1947 to 1974 (Cohen and Felson, 1979:588). Cohen and Felson based their theory on a rational choice model, in which people make rational decisions in ways that will be to their advantage, with as little disadvantage as possible (Akers and Sellers, 2004:26). The Rational Choice Theory is based in the classical school of criminology (Miller et al., 2006: 4).

When Cohen and Felson proposed the theory, they clearly defined the concepts used, and the propositions they wished to express. Their proposition was that for a crime to occur, you needed three elements: motivated offender, suitable target, and lack of a capable guardian (Cohen and Felson, 1979:588), and those three elements must converge in space and time through routine activities (Akers and Sellers, 2004:33). They clearly define what each element 
is, and that if you remove any of the elements a crime would not occur (Akers and Sellers, 2004:33).

A motivated offender, is a person who is motivated enough to commit a crime (Akers and Sellers, 2004:33), while suitable target, which is the second element, was part of the theory that was expanded on by the acronym VIVA, which stands for Value, Inertia, Visibility, and Accessibility (Miller, 2006:82). Value according to Miller (2006) is dependent upon the person assessing the object or person, and it does not depend on the actual economic worth of the object; Inertia is the size of the target and the ability of the offender to remove that object, or in the case of an offender attacking a person; it can be if the offender feels he/she can overcome the victim; Visibility refers to whether or not the offender knows that the target is there while Accessibly is if the offender is able to have access to the target, and then if they can retreat or escape. The last requirement, absence of capable guardians, occurs through everyday people as they continue their routine activities, and prevent a crime either overtly or not (Cohen and Felson, 1979:588).

This theory by Cohen and Felson seeks to explain criminal violations, and they give the parameters in which the violations will occur. Cohen and Felson give a wide range in which the theory can be applied. A major advantage of this theory is that it can be applied to many different types of studies and crimes including homicides, hot spots of crime, property and violent crimes, natural disasters, and even internet crimes (Akers and Sellers, 2004:35-6). The theory, although wide enough in the range in phenomena it wishes to explain, fails to account for why some individuals are motivated offenders (Akers and Sellers, 2004:38). It makes an assumption that motivated offenders will just be in a particular place when their target is there and there is a lack of a capable guardian. In Nigeria, this is not just an assumption; this theory aptly explains the common scenario where lots have been said and heard about people taking to criminality in order to meet their social responsibility. Take, for instance, armed robbery along the highway, criminals usually engaged in their nefarious activities after noting the absence of 'capable' guardian, which is the Police Highway patrol. The concept of 'capable guardian' could also imply the Police patrol that is adequately equipped to handle unpleasant situation if by chance the robbers are trying to resist arrest. Police patrols that involve themselves in extortion of money from motorists cannot be classified as 'capable guardian' at all.

Capable guardian may come in form of provision of infrastructural and technological facilities, such as street light and closed circuit television cameras on the street (Danner, 2003) as well as motorable roads. Except for recent time when information abounds about the daredevil robbers that operate during the daylight, their activities are mostly during the dark. Where they are operating in the daylight, closed-circuit cameras will assist in tracking them. It was also noted that the dilapidated parts of the highways were always the hotspot for criminal activities. The position here is that existence of these 
facilities will deter the activities of highway robbers or reduce it to minimal level.

A closer analysis of the routine activities theory shows an interpretation in two major features within the context of 'opportunity' (Bottons and Wiles, 1997:327):

1. There is a strong interest in the day to day activities of potential victims of crime and of those potentially able to offer 'natural surveillance', and

2. Routine activities theory has an explicitly special dimension of crime which emphasizes the fundamental human ecological character of illegal acts as events which occur at specific locale, space and time involving specific persons and /or objects.

Finally, this theory embeds the concept of opportunity within the routine parameters of the day to day lives of ordinary people, and in doing so also emphasizes the spatial - temporal features of opportunity (Bottons and Wiles, 1997).

\section{Methodology}

This covers the scope of the study, the instruments used to collect data for the study, the target (study) population and sample size as well as data analysis.

\section{Scope of the study}

This was limited to the Ibadan-Sokoto transport corridor. This corridor covers approximately 850 kilometres of surfaced road and can be broken down as follows:

$\begin{array}{lclcc}\text { Ibadan } & - & \text { Ilorin } & - & 165 \text { kilometers (Oyo/Kwara States) } \\ \text { Ilorin } & - & \text { Jebba } & - & 100 \text { kilometers (Kwara State) } \\ \text { Jebba } & - & \text { Mokwa } & - & 40 \text { kilometers (Niger State) } \\ \text { Mokwa } & - & \text { Makera } & - & 60 \text { kilometers (Niger State) } \\ \text { Makera } & - & \text { Kontagora } & - & 80 \text { kilometers (Niger State) } \\ \text { Kontagora- } & \text { Jega } & - & 265 \text { kilometers (Niger/Kebbi States) } \\ \text { Jega } & - & \text { Sokoto } & - & 140 \text { kilometers (Kebbi/Sokoto States) }\end{array}$

\section{Research Instrument}

The study adopted qualitative methodology of In-depth Interviews (IDIs), Focus Group Discussions (FGDs) and Observations. Structured guides were developed for the IDIs and FGDs and pre-tested to ensure validity. Data from responses offered by respondents and discussants in the FGD and IDI guides were summarized using content analysis and grouping of relevant information. Three trained field assistants were engaged for the field survey. Three languages: Yoruba, Hausa and English (and in some occasions Pidgin English) 
were used for the IDIs; the transcribed scripts were later translated into English.

\section{Study Population}

The selection of the respondents for this study was purposive. The respondents involved in in-depth interviews (IDIs) included the commuters, their relatives (who accompanied travellers to the park), National Union of Road Transport Workers (NURTW) officials and Police officers. The respondents for the Focus Group Discussions were limited to drivers from Car/Buses and Truck/Trailers sections of Ibadan/Sokoto transport corridor. The Police Officers were selected from Ojoo Divisional Police headquarters which has jurisdiction over the Motor Park.

The loading schedule of the Cars/Buses and Trucks/Trailers make involvement of the drivers in FGDs appropriate. The drivers are always at ease awaiting their turns to load, which may not take place until the following day. Their assistance and cooperation were sought to participate in the study, and only those who were willing eventually took part in this study. The breakdown of this is as displayed in Table 1.

Table 1: Breakdown of IDI and FGD Sessions

\begin{tabular}{|c|c|c|c|}
\hline IDI Respondents & Male & Female & Total \\
\hline Commuters/Passengers & 33 & 14 & 47 \\
\hline Relatives of travellers & 13 & 5 & 18 \\
\hline NURTW Officials & 5 & - & 5 \\
\hline Police Officers & 2 & - & 2 \\
\hline Total & 53 & 19 & 72 \\
\hline Respondents in FGDs & $\begin{array}{l}\text { Less than } 40 \text { years of } \\
\text { age }\end{array}$ & $\begin{array}{l}\text { Above } 40 \text { years of } \\
\text { age }\end{array}$ & Total \\
\hline Car section & $\begin{array}{l}18 \text { (3 sessions of } 6 \\
\text { respondents each) }\end{array}$ & $\begin{array}{l}12 \text { ( } 2 \text { sessions of } 6 \\
\text { respondents each) }\end{array}$ & 30 \\
\hline Bus section & $\begin{array}{l}18 \text { (3 sessions of } 6 \\
\text { respondents each) }\end{array}$ & $\begin{array}{l}12 \text { (2 sessions of } 6 \\
\text { respondents each) }\end{array}$ & 30 \\
\hline $\begin{array}{l}\text { Trucks (Mitsubishi } \\
\text { Canter/911) }\end{array}$ & $\begin{array}{l}12(2 \text { sessions of } 6 \\
\text { respondents each })\end{array}$ & $\begin{array}{l}18 \text { ( } 3 \text { sessions of } 6 \\
\text { respondents each) }\end{array}$ & 30 \\
\hline Trailers section & $\begin{array}{l}12(2 \text { sessions of } 6 \\
\text { respondents each })\end{array}$ & $\begin{array}{l}18 \text { ( } 3 \text { sessions of } 6 \\
\text { respondents each) }\end{array}$ & 30 \\
\hline Total & 60 & 60 & 120 \\
\hline
\end{tabular}

\section{Procedure for Data Analysis}

Open code software was utilized to analyze the data collected for this work. In addition, verbatim quotations were utilized to illustrate some points during interpretation of results. 


\section{Findings and Discussion}

\section{Crime Situation and Perception of Safety along the Corridor}

Discussions during the IDI and FGD sessions focused on a 5 - year recurring assessment of security and safety along the Ibadan-Sokoto Road Transport Corridor. Respondents were unanimous on the growing crime rate on this corridor. In ranking the problems and danger on the corridor, crime came top followed by "bad roads". A male passenger respondent said:

The greatest problem on this route is that your vehicle can be attacked at any moment... maybe after that you can talk of bad roads (Male IDI, Passenger).

Other respondents reflected on past security situation along Nigeria highways and compared this with the present reality. In the words of one of them:

This route used to be safe some years back... but now things are terrible. Then you can travel at any period of time without fear of bad roads or armed robbers, but this is no longer the case now (Female IDI, Passenger).

A driver emphatically stated that:

The major problem we encounter, I mean we drivers, are thieves on the highway and bad roads... A lot of drivers have bitter experience as a result of their encounter with robbers be it night or day time. The particular hotspot for this nefarious activity is mostly between Bode Sadu to Mokwa and subsequently Kontagora towards Sokoto (FGD, Bus Driver).

Respondents were also unanimous on the rising trend of this problem as well as its growing sophistication. Corroborating earlier position of some drivers that took part in this study, the Chairman of NURTW-Sokoto unit submitted that:

Many of our drivers have experienced robbers attacking them... they leave Ibadan and before they get to Ilorin, they would have been robbed of all their belongings... money and other materials...we have lost three drivers in the last eight months (IDI, NURTW Chairman).

In another instance, some respondents shed light on the specific time when rate of crime on the highway is particularly high. According to another parker in FGD sessions: 
The crime situation is usually worrisome during festive periods like Christmas, New Year, eid-el Kabir. The point here is that people usually travel en-mass in the course of celebrating with their families. It thus provides ample opportunity for the men of the underworld to attack the travellers at that point in time (FGD, Car Driver).

The rise in the crime trend along this corridor could in itself reflect the general trends in National Crime figures as Table 2 reflects. According to the table, crimes that pertain to robbery are part of those that are increasing at significant rates in the country. The implication of this is that other forms of crime as reflected in the table are likely to progress from the neighbourhood to the streets of which highways are inclusive. Except reasonable action is taken about this, one may not rule out the possibility of extension of tentacles by the perpetrators of these crimes to the highways in order to increase their returns. This thus portends danger for the general well being and overall development of the country, because fear of insecurity means reduction in the ability of the people to engage in economic venture that may involve travelling to other parts of the country. Where this becomes the case, it means little profit and fewer investments. At the same time, this is likely to discourage foreign investment due to the existing market trends and factors influencing the trends.

The general perception of safety and crime situation as reflected in the data from IDIs and FGDs is a manifestation of growing level of insecurity in the country. The ample knowledge of this by the respondents shows the general awareness of this among the people. One possible effect of this is the growing fear of crime by the people with its attendant problems. Such fear and its effects are reflected in the words of a female IDI respondent. According to her:

With the rate at which this menace is going now, every journey I make is borne out of necessity, Even the one I'm going now is half-hearted; I just pray that we are not attacked. Where possible I will prefer not to make this trip... I am just praying for total protection because nobody could tell what will happen in the next few hours (Female IDI, Passengers). 
Table 2: Summary of Crime Statistics in Nigeria (1997-2006)

\begin{tabular}{|c|c|c|c|c|c|c|c|c|c|c|}
\hline Offences & 1997 & 1998 & 1999 & 2000 & 2001 & 2002 & 2003 & 2004 & 2005 & 2006 \\
\hline Burglary & 7706 & 5548 & 4928 & 3768 & 5523 & 2683 & 2769 & 2908 & 4907 & 3501 \\
\hline Gambling & 203 & 158 & 264 & 189 & 263 & 229 & 148 & 165 & 631 & - \\
\hline $\begin{array}{l}\text { Armed } \\
\text { Robbery }\end{array}$ & 2419 & 2286 & 1877 & 2809 & 2809 & 3889 & 3497 & 3142 & 2074 & 2063 \\
\hline $\begin{array}{l}\text { Store } \\
\text { Breaking }\end{array}$ & 4235 & 4036 & 3045 & 2446 & 2446 & 2973 & 2790 & 2768 & 4887 & 3510 \\
\hline Suicide & 272 & 313 & 323 & 146 & 241 & 152 & 191 & 131 & 128 & 199 \\
\hline $\begin{array}{l}\text { Receiving } \\
\text { Stolen } \\
\text { Property } \\
\end{array}$ & - & - & - & - & - & - & - & 2733 & 3812 & 7308 \\
\hline Murder & 1730 & 1670 & 1645 & 1255 & 2120 & 2170 & 2136 & 2550 & 2074 & 2000 \\
\hline Assault & 42815 & 40764 & 3358 & 17909 & 37531 & 39329 & 24125 & 29863 & 33991 & 32838 \\
\hline $\begin{array}{l}\text { Demand/ } \\
\text { Menace }\end{array}$ & 128 & 112 & 63 & 133 & 112 & 88 & 80 & 56 & 84 & 63 \\
\hline $\begin{array}{l}\text { House } \\
\text { Breaking }\end{array}$ & 8562 & 7847 & 5929 & 3636 & 6059 & 5448 & 4706 & 4713 & 6371 & 4774 \\
\hline $\begin{array}{l}\text { Unlawful } \\
\text { Possession }\end{array}$ & - & - & - & - & - & - & - & 538 & 8772 & 8666 \\
\hline Arson & - & - & - & - & - & - & - & 1289 & 1268 & 1010 \\
\hline $\begin{array}{l}\text { Attempted } \\
\text { Suicide }\end{array}$ & 58 & 43 & 30 & 41 & 27 & 29 & 38 & 19 & 20 & 289 \\
\hline $\begin{array}{l}\text { Forgery of } \\
\text { Currency } \\
\text { Note }\end{array}$ & 1245 & 718 & 483 & 489 & 573 & 528 & 576 & 50 & 58 & - \\
\hline $\begin{array}{l}\text { Rape/Incident } \\
\text { Casualty }\end{array}$ & 2585 & 2249 & 2241 & 1529 & 2284 & 084 & 2253 & 1626 & 1835 & 1718 \\
\hline $\begin{array}{l}\text { Attempted } \\
\text { Wounding }\end{array}$ & 14720 & 14362 & 15931 & 15241 & 15241 & 17580 & 17666 & 18733 & 22558 & 2643 \\
\hline $\begin{array}{l}\text { False } \\
\text { pretence/ } \\
\text { Cheating/ } \\
\text { Fraud } \\
\end{array}$ & 11950 & 12037 & 9996 & 7927 & 10234 & 9134 & 9508 & 9532 & 9580 & 6395 \\
\hline Forgery & - & - & - & - & - & - & - & 650 & 551 & 519 \\
\hline $\begin{array}{l}\text { Theft/other } \\
\text { Stealing }\end{array}$ & 58095 & 54506 & 42974 & 29127 & 40769 & 35231 & 33124 & 37289 & 46114 & 2901 \\
\hline $\begin{array}{l}\text { Child } \\
\text { Stealing }\end{array}$ & 303 & 107 & 147 & 101 & 116 & 55 & 39 & 45 & 80 & 59 \\
\hline Kidnapping & 377 & 282 & 342 & 243 & 349 & 377 & 410 & 349 & 789 & 11 \\
\hline $\begin{array}{l}\text { Coining } \\
\text { Offence } \\
\end{array}$ & 14 & 14 & 7 & 4 & 32 & 6 & 16 & 7 & 23 & - \\
\hline $\begin{array}{l}\text { Breach of } \\
\text { public peace }\end{array}$ & 7519 & 6765 & 395 & 7532 & 7532 & 2324 & 7298 & 6080 & 7967 & - \\
\hline $\begin{array}{l}\text { Unnatural } \\
\text { offence }\end{array}$ & 435 & 516 & 456 & 376 & 434 & 277 & 306 & 7967 & 371 & 361 \\
\hline $\begin{array}{l}\text { Slave } \\
\text { Dealings } \\
\end{array}$ & 70 & 11 & 21 & 11 & 45 & 17 & 18 & 371 & 14 & 11 \\
\hline Perjury & 97 & 20 & 12 & 16 & - & - & - & 14 & - & - \\
\hline $\begin{array}{l}\text { Bribery/ } \\
\text { Corruption }\end{array}$ & 100 & 138 & 75 & 48 & - & - & - & - & - & - \\
\hline Manslaughter & 18 & 27 & 14 & 101 & - & - & - & - & - & - \\
\hline $\begin{array}{ll}\text { Escape from } \\
\text { lawful } \\
\text { custody }\end{array}$ & 743 & 484 & 352 & 294 & - & - & - & - & - & - \\
\hline
\end{tabular}

Source: The Cleen Foundation (2009)

The fear is not limited to the passengers and drivers alone; relatives of the passengers equally expressed their worries. Many revealed that they came to see off their relatives to the Motor Park in order to collect information on the vehicles they were to board, and to give moral support to their relatives to quell the fear of uncertainties on the road. According to a respondent:

I am here to see my wife off on an official journey that is taking her to Sokoto. She does this on quarterly basis, and I took it as a matter of duty to take her to the Park. I wait till the vehicle takes off after the 
last passenger has boarded the vehicle. On each of these occasions, I always stay by her, tease her in order to create a lighter atmosphere that devoid of anxiety; as the journey is about to commence, I will pray with her to commit the journey unto the hands of God. This has been helping the family greatly. As the journey progresses, the next line of action is constant communication on handset to know situation of things (Male IDI, Relative to a Passenger).

\section{Nature of Crime along the Corridor}

Further discussions revealed the nature of crimes on the corridor has been described as mostly violent in nature. This is attributed to the preparedness of the criminals to ensure that they succeed in their acts. A respondent submitted thus:

We the drivers are the target... they aim at us and as soon as we are hit they descend on the passengers and rob them of their property at gun point. Anybody that dares to resist is usually dealt with ruthlessly, in most cases, such a person is killed in a violent way (FGD, Bus Driver).

Another driver painted the situation in a more pathetic way, according to him:

Taking a look between 1978 and 1990s the thieves of that time are not as sophisticated as those of today. You can imagine thieves at that time robbing with knife and cutlass not gun. But those robbing now are very deadly and wicked and any driver who fails to stop for them when flagged down will be killed (FGD, Truck Driver).

On similar note but with different revelation, a respondent said:

In some pathetic situations, female passengers are raped in addition to dispossessing them of their jewelleries, handsets and money. You can imagine the horror we live with (FGD, Car Driver).

Discussions did not reveal any ethnic factor amongst the offenders as the languages used by offenders vary by region and section along the corridor. However, some fear spots were discernable along the corridor. Deeper analysis of submission by the different categories of respondents revealed that there is no axis of the corridor that is safe. An official of NURTW, Shasha/IbadanSokoto unit said:

Bad axis with long stretch of bad road is usually the hangout of the criminals. In some cases, the bad portion of the road may not stretch significantly, but may be in a deplorable condition that requires slow 
driving of the vehicle to prevent breakdown of the vehicle, accident, rapid wearing-away of essential parts of the vehicles. It is at that point that the robbers will file out to attack the vehicles and their occupants (IDI, Vice Chairman, NURTW Sokoto Unit).

Lending credence to this, a participant in one of the FGD sessions confirmed the position of the Vice Chairman in terms of effects of bad road on rate of crime. He was more particular about the axis noted as being notorious for this nefarious activity. In his words:

From Ibadan to Sokoto, the most notorious areas are in Niger State... Niger state area is a death trap in terms of bad roads and criminal activities (FGD, Trailer Driver).

There was a consensus in the linkage between bad roads and fear spots by respondents. As a respondent commented:

As soon as you approach areas where roads are bad, your heart beat goes up because anything can happen... thieves can appear from nowhere to come and perpetrate what they are best known for (Female IDI, Passenger).

Although respondents argued that crime is ever present on the corridor, discussions point to the fact that forest areas along the corridor have higher potential for crime occurrence. A respondent narrated further that:

Forest areas are one of the major areas where I fear most on the corridor...in such places, you cannot easily see through the criminals' hideouts. They seize the opportunity to attack the vehicles and run back into the forests (Female IDI, Passenger).

Marauders were also reported to sometimes disguise themselves in police uniforms. While the timing of the criminal activities is not predictable, it is more likely when the route is lean in traffic especially between 1-2 pm and at dusk.

\section{Effects on the Road Transport Sector}

From the cases reported, it is obvious that the fear of crime by passengers has begun to have effect on the road transport business. The data gathered from the entire stakeholders in transport business that took part in IDIs and FGDs lend credence to this. A respondent in the FGDs submitted thus: 
The situation is so pathetic that those of us in the business are now affected as most people prefer to travel with Luxurious Buses as against cars and small buses. This is simply because the operators of Luxurious Buses provide securities unlike the case with small buses and cars where government does not permit the use of or possession of arms (FGD, Truck Driver).

On the part of the passengers, the fear has effects on their rate of travelling. In the words of one of the passengers:

The number of vehicles loaded per day has reduced... and any vehicle that is not loaded by 12 noon has no hope of loading again for the day because no passenger would dare venture to travel at night because of risk and uncertainties involved (Male IDI, Passenger).

In another instance, the escalation and prevalence of crime especially along the highways is being ascribed to failure on the part of the victims to report to the appropriate quarters for necessary action. The Police officers that took part in the study revealed that crime reporting plays a crucial role in crime management; however, they revealed that most victims hardly report to the police. This position was however faulted by some passengers who opined that the fact that the passengers are on transit at the time the crime occurred is a setback on successful monitoring and prosecution of such cases. This according to them hardly give the police the needed opportunity of seeing the case through either in terms of constant appearance of witness to supply one information or the other as occasions demand. According to one of the passengers:

What will the police do in this case... don't forget the passengers are on transit.... if you are in position of such victims who are on transit (God forbid) will you come back to the station to come and ask how far the case has gone? I'm very sure, you cannot, therefore there is the need for the Government to see to it that necessary stone is left unturned in the course of making our highways crime free (Male IDI, Passenger).

\section{Stakeholders' Response to crime}

As precautionary measures towards eradicating crime along the highways or its reduction to the barest minimum, some ideas were generated as the best ways out of the menace. The ideas emanated from both sides of the divide passengers and transport operators. These are as enumerated below:

- Searching passengers and goods before take-off of vehicles. This will help to ensure that robbers are not boarding the vehicle with the intent to perpetrate evil in the middle of the journey. 
- Barring passengers from making GSM calls in the course of the trip; this is because it was believed that some passengers stay in touch with robbers keeping them abreast of the activities of the vehicles.

- Documenting details of passengers at point of departure in order to know whom to contact in the course of unforeseen circumstances.

- Collaborating with state Anti-Robbery Squad vide the Save-Our-Soul calls.

- Reduction of cash at hand by passengers and drivers so as to make highways less attractive to criminals.

- Use of alternative routes.

- Operational scheduling of movement periods by transport operators

- Going in convoys/groups

- Drivers of buses and trucks have increased ownership of guns and weapons of violence for self-defence

- Reduction in trips by passengers

While the Special Anti-Robbery Squad of the different states along the corridor has been reported helpful, a major response that has emerged along the route is the local vigilante personnel. Observations along the corridor showed that members of this group of 'private security' guards dotted some seemingly dangerous spots. Armed with local dane guns, they often wear uniforms that differ across sectors along the corridor, but distinct enough to give them a paramilitary outlook. They appear untrained (professionally) and tend to rely on indigenous knowledge of game hunting. They have no training on modern policing and also lack the sophistication which the criminals along the corridor have. But they tend to have the confidence and courage imbued with these local security outfits. These groups/outfits that come under different names ('Damusa', 'Olode', 'Oodua People's Congress (OPC)', 'Yanbanga', 'Dambakan') depending on the locality have been adjudged by respondents as very effective. A driver who has been operating along the corridor since 1976 submitted thus:

We like them on the way, when they (thieves) are robbing at any point of the road where they could be located and they are informed, they will go there. They don't run from thieves. We are always happy and feel okay when we see them along the way but once we leave their area, the fear will return (IDI, Bus Driver).

Comments as above raise the question on the trust and confidence that Nigerians have for the Police (Okunola, 2006). This equally calls to question the efficiency and effectiveness of the Highway Patrol unit of the Nigeria Police. The presence and role of this unit did not elicit palatable comments from some of the respondents. According to a respondent: 
Those Highway Patrol People?...forget them... they just appear to extort money from the drivers... when serious robbers' operation happens they are nowhere to be found Highway patrols are not doing anything on the highway (Female IDI, Passenger).

\section{Conclusion}

It is obvious that fear of crime on Nigeria highways has become a nuisance to the transport industry and the general populace making use of the services within it. The fear is further compounded by the nature of the roads, which as most respondents opined has deteriorated greatly over time. The attitude of the people towards the Police is negative. This therefore calls to question the overall essence of the highway patrol system of the Nigeria Police.

In the light of the foregoing, it can be concluded within the backdrop of the theoretical framework adopted in this study that in the daily routine activities of commuters (a geo-spatial activity), armed robbers or potential criminals are seizing the socio-spatial temporal absence of guardians and seizing the opportunity in the absence of capable guardians (highway policing) to unleash terror and violence on commuters. Experiences of victims have sent jitters into the minds of potential commuters. Reported cases especially by the media have served to increase the degree of fear amongst commuters with increasing socioeconomic consequences including uncertainty and despair. The situation is now such that if urgent steps are not taken to restore the confidence of highway users, it may lead to total crippling of movement of persons and goods by road (ThisDay, 2006; The Statesman, 2006). Going by the necessity of movement of persons and goods as crucial tools for social and economic development in all societies, it would be antithetical for this to be dislocated by the activities of highway armed robberies.

\section{Suggestions}

The following suggestions are proffered:

- Increased routine patrol to reduce the spatio-temporal features of opportunity. Since both day and night travels are prone to mishaps and criminal activities, government should wake up to its responsibility of securing the roads. The government needs to wake up to the basic tenets of its existence in which provision of safety for the citizenry is inclusive. One way to achieve that is to replace the ubiquitous but inefficient police check-points with highly motivated and well equipped patrol teams. That would introduce unpredictability into the operations of the law officers, which could unsettle the robbers. With proper surveillance, the highways can be rid of felons.

- With the growing on-line banking in the country, travellers should be discouraged from carrying huge amounts of money. There should be full 
commitment to the need to promote paper economy, as against cash economy that currently operates in the country.

- In addition to safeguarding the roads and making them more motorable, government should also expedite action on revamping the railways. That would reduce pressure on the highways. Even in advanced countries where road networks are far more dependable, the railway system constitutes a major means of transportation. A reliable railway would, no doubt, reduce the enormous security challenges posed by the roads.

- There is need for constant patrolling of areas noted to be dangerous, while aerial surveillance should also be introduced to curb the menace of the existing criminals and discourage potential criminals.

- Given the correlation between bad roads and occurrence of crime, government at all levels (especially federal) will have to increase its efforts which should not be limited to road construction alone but also in the repair of bad ones.

- As suggested by the majority of respondents, there is an urgent need to increase police posts along the highways in Nigeria.

- Finally, Transport Security Administration should be established not only to ensure security at points of departure but also monitor the routes to prevent armed attacks on Nigerian highways.

The above suggestions raise a major issue within the various reforms which Nigeria Police has gone through. In view of this, it is glaring that the reform in the police has not had any meaningful impact on security on our highways hence the need for real reform that will overhaul the entire highway security system in the country. The contentious issues include whether the vigilante groups, on whom the officials of NURTW have confidence, or the state should take the lead in protecting the highway, as well as the need to increase resource allocation for security of the highways.

The whole scenario points at the need of finding ways of extending the community policing strategy into security on the highways in Nigeria. After all, the vigilante groups represent an attempt by communities on the corridor to make their input into the security system in their respective segments along the corridor.

\section{References}

Adebayo, B. F. 2009. "Burden on Nigerians and Nigerian road users" Weekly Trumpet (Newspaper), (May 7 edition).

Agbola, T. 1997. Architecture of Fear: Urban Design and Construction Response to Urban Violence in Lagos State, Ibadan: IFRA Publication. 
Akers, R. L. and Sellers, C. S. 2004. Criminological Theories: Introduction, Evaluation and Application (4th edition), Los Angeles, California: Roxbury Publishing Company, 2004.

Akiwunmi, O. 2001. 'Princes as Highway Men. A Consideration of the Phenomenon of Armed Banditry in Precolonial Borgu' Cahiers d'etudes africaines, 2001/2, 162, p.333-379.

Albert, I. O. 2003. "The concept of security in the context of urban crimes and Segregation in West Africa" in Faurchard, L. and Albert, I.O (eds), Security Crime and Segregation in West African Cities Since the $19^{\text {th }}$ Century Ibadan: IFRA Publication. Pp. 53-69.

Alemika, E. E. O. 1997. Criminal Violence and Insecurity in Lagos State Nigeria Africa Peace review. Journal of Centre for Peace and Conflict Resolution. Vol. I/2 Pp. 72-95.

Anthony, E. B and Wiles, P. "Environmental Criminology" The Oxford Handbook of Criminology ( $2^{\text {nd }}$ Edition), Oxford Clarendon Press, pp. 305350.

Bottoms, A. E. and Wilies, P. 1997. Explanations of Crime and Place. In Evans, D. J., Fyfe, N.R. and Herbert D.T. (Eds). Crime, Policing and Place Essays In Environmental Criminology. Pp. 11-35. London: Routeledge.

Brantinghaan, P. J. and Brantinghaan, P. L. 1981. "Notes on the Geometry of Crime" in Environmental Criminology, Prospect Heights: Waveland Press. pp. 27-57.

Buhari, M. 2000. "The Role of Infrastructural Development and Rehabilitation in Sustainable Economic Growth in Nigeria"; Paper presented at the All Peoples Party Economic Summit, held at Ladi Kwali Conference centre, Sheraton Hotel Abuja, $9^{\text {th }}-10^{\text {th }}$ November 2000; accessed at http://www.Buhari2003org//speeches.htm.

Chikwanha, A. B. 2007. "Enhancing the Delivery of Security in Africa: Complementing the APRM AND working" to the African Union Criminal Justice Issue Paper 2007.

Cleen: www.kabissa.org/cleen; Accessed on $26^{\text {th }}$ June 2009.

Cohen, L. E.; Felson, M. 1979. "Social Change and Crime Rate Trends: A Routine Activity Approach" American Sociological Review, Vol. 44. pp. 588-608.

Danner, T. A. 2005. 'Violent Times: A case study of the Ybor city Historic District', Criminal Justice Police Review, 14(1).

Dawha, E. 1996. Yan Daba, Yan Banga and Yan Daukar Amarya: A Study of Criminal Gangs in Northern Nigeria, Ibadan: IFRA.

Eck, J. E. 1995. "Examining Routine Activity Theory: A Review of Two Books" Justice Quarterly, Vol. 12, pp. 783-797.

Enekwechi, C. 2008. "Curbing Armed Robbery Menace on Our Highways" accessed at http://www.dailytrustonline (09-07-2008 edition).

Fabiyi, O. 2004. Gated Neighbourhoods and Privatisation of Urban Security in Ibadan Metropolis. French Institute for Research in Africa. 
Falola, T. 1996. "The Brigandage and Piracy in Nineteenth Century Yoruba", Journal of Historical Society of Nigeria (1995-1996), XII (1-2); 83- 105.

Federal Government of Nigeria, 2003. "Strategic Conflict Assessment: Consolidated and Zonal Reports", Abuja: Institute for Peace and Conflict Resolution.

Felson, M. 1994. Crime and everyday life, (Third edition), Thousand Oaks, CA: Pine Forge press.

Filani, M. 2003. "Advancing the cause of Private Participation in the Road transport Sub-sector in Nigeria" A paper presented at $10^{\text {th }}$ Anniversary celebration of the Association Bus Company limited, May 14, 2003, Ikeja, Lagos.

Fisher, A. and Nadan, D. 1995. "Violence and Violent Crime in the NorthEast" accessed at http://www.history.ac.uk/ihr/resources/theses/tco2 on $12 / 01 / 2011$.

Ginifer J. and Ismail O. 2003. Armed violence and poverty in Nigeria (Mini case study for the Armed Violence and Poverty Initiative), University of Bradford (March 2005).

Husher, N. 2005. "Nigeria, Giant of Africa"; HST 142.

Ikhurionan, E. 2003. "Robbery Kingpin, Tidjani Moved to Nigeria: Confesses to being receiver of stolen goods" accessed at http://news. biafranigeriaworld.com/archive/2003/sep/26/0115.html.

Larkin, E. 2008. "A Highway Code for Vulnerable Motorists" accessed at http://www.highwaycodes.com.

Maxfield, M. G. 1984. "The limits of Vulnerability in Explaining Fear of Crime: A Comparative Neighbourhood Analysis" Journal of Research in Crime and Delinquency. Vol. 21 Pp.233-250.

Miller, J. M.; C. J. Schreck, and R. Tewksbury, 2006. Criminological Theory: A Brief Introduction, Boston: Pearson/Allyn \& Bacon, 2006.

Obono, O. 2007. "A Lagos Thing: Rules and Reality in the Nigerian Megacity" Georgetown Journal of International Affairs, Summer/Fall 2007.

Reid, T. 2008. Crime and Criminology ( $11^{\text {th }}$ Edition), New York McGraw Hill Higher Education.

Shettima, A. G. 2006. "Policing the Police" Amana Online Journal accessed at http://www.highways/Amana Online.htm.

Sundeen, R. and Mathieu, J. 1976. The Fear of Crime and its Consequences among Elderly in the Urban Communities, 3(6):211-9.

Umaru, T. A. 2004. "Our porous borders and security implications" Journal of Culture and Environmental Studies, Vol. 15(2).

Uzokwe A. O. 2003. "Why Diasporans May Not Return to Nigeria?" accessed at http://www.nigeriaworld.com.

http://www.widernet.org/OurJosWeb/CM/OntheRoad/ontheroad.htm (1999). 
Wahab, A. Z. 2008. "The hazard on the passengers: The case of highway security" accessed at http://www.vitanet.org/hazard/security/ XXProads.html/.

Wikipedia, 2009. "Transport in Nigeria" accessed at http://en.wikipedia. org/wiki/transport_in_Nigeria.

Williams, P. and Dickinson, J. 1993. "Fear of Crime: Read All About It? The Relationship between Newspaper Crime Reporting and Fear of Crime", British Journal of Criminology, 33:33-56.

Zedner, C. 1997. "Victims" In Maguire, M. Morgan, R. and Reiner, R. (eds). The Oxford Handbook of Criminology ( $2^{\text {nd }}$ Edition), Oxford Clarendon Press.

\section{Newspapers}

Vanguard, January 28, 2003.

This Day News, January 26, 2003

Guardian, January 25, 2003

Thisday (2006). Highways to Hell: 09/10/2006

The Statesman, (2006). Highways to Hell: 09/10/2006. 